\title{
THE IMPACT OF THE OXIDISING AGENT TYPE AND COAGULANT TYPE ON THE EFFECTIVENESS OF COAGULATION IN THE REMOVAL OF POLLUTANTS FROM UNDERGROUND WATER WITH AN INCREASED CONTENT OF ORGANIC SUBSTANCES
}

\author{
Izabela KRUPIŃSKA \\ Faculty of Civil Engineering, Architecture and Environmental Engineering, University of Zielona Góra, \\ Institute of Environmental Engineering, 15 Prof. Z. Szafrana St, 65-516 Zielona Góra, Poland
}

Submitted 18 Feb. 2015; accepted 23 Oct. 2015

\begin{abstract}
The article presents the results of studies concerning the impact of the method of Fe(II) ion oxidisation on the effectiveness of coagulation in the removal of pollutants from underground water with an increased content of organic substances (TOC up to $5.338 \mathrm{mgC} / \mathrm{dm}^{3}$ ). In order to oxidise the $\mathrm{Fe}$ (II) ions before the coagulation process, the underground water was subjected to aeration, or either potassium manganate (VII) or hydrogen peroxide were dosed in the stoichiometric amount in view of the concentration of Fe (II). The efficiencies of three coagulants were compared: that of aluminium sulphate (VI), polyaluminium chloride (PAX XL-60) and iron (III) sulphate (VI) - PIX-112. Coagulant doses expressed in $\mathrm{mgAl} / \mathrm{dm}^{3}$ or $\mathrm{mgFe} / \mathrm{dm}^{3}$ and changed within the range of 1 to $6 \mathrm{mgAl}(\mathrm{Fe}) / \mathrm{dm}^{3}$. Volume coagulation was performed in $1-\mathrm{dm}^{3}$ groundwater samples using 1-minute rapid mix (250 rpm) and 25 -minute slow mix $(30 \mathrm{rpm}$ ) followed by 2-hour sedimentation. It has been proven that the type of oxidising agent and coagulant, as well as their dose, co-determines the effectiveness of the removal of the pollutants. Among the used methods of iron (II) oxidisation, the best effects have been achieved by potassium manganate (VII) with regards to the effects of the reduction of colour, turbidity, concentration of manganese and organic substances, and with regards to the extent of total iron removal, oxidisation with dissolved oxygen was the most effective solution. Hydrogen peroxide was the least useful oxidising agent. Regardless of the oxidising agent the best results in the removal of pollutants in the coagulation process were produced by the coagulant: pre-hydrolysed polyaluminium chloride PAX XL-60, and the worst by the iron coagulant: iron (III) sulphate (VI). Analysis of the results of the studies also showed that the effectiveness of pollutant removal from the underground water in the coagulation process was decreased together with an increase in the value of the $\mathrm{TOC} / \mathrm{Fe}_{\text {tot }}$ only in the case of water samples which, after aeration, differed in terms of the coefficient of organic substances and total iron (D). Such a relationship was not found when potassium manganate (VII) and hydrogen peroxide were used for oxidisation before the coagulation process.
\end{abstract}

Keywords: groundwater, organic substances, volume coagulation, aeration, potassium manganate (VII), hydrogen peroxide.

\section{Introduction}

Poland is one of the countries whose water reserves are relatively small. This is especially true as far as surface water is concerned. The usable reserves of groundwater are estimated in Poland as $15.6 \mathrm{~km}^{3}, 65 \%$ of which is water from the quaternary aquifer. $85 \%$ of abstracted water is used for drinking and economic purposes and 15\% for manufacturing purposes. In Poland, groundwater is used by 185 enterprises and water supply companies, surface water by 10 water supply companies and both sources are used by 29 water supply companies. Very few of the water supply companies abstract groundwater whose physicalchemical composition satisfies the requirements for water for human consumption, and about $34 \%$ of abstracted groundwater is low quality water with an increased content of iron, manganese and organic substances and it has to be treated in a number of stages with costly and technologically difficult methods (Gimbel et al. 2008). In the case of underground waters containing increased concentrations of organic compounds, Fe(II) and Fe(III) ions as well as their hydrocomplexes create stable iron-organic bonds and the water is characterised by its raised colour

Corresponding author: Izabela Krupińska

E-mail: i.krupinska@iis.uz.zgora.pl 
and turbidity. Depending on the type and concentration of the organic substances, the $\mathrm{pH}$, the oxidising-reduction potential and the ionic composition of water, the iron ions and their hydro complexes may, together with organic ligands, create compounds or complexes can form colloidal solution. Of major significance in the creation of ionorganic compounds are the humic acids (Krupińska et al. 2013; Calace et al. 2001; Jobin, Ghosh 1972). Based on the analysis of a number of vulnerabilities of metals to create bonds with humic acids, a conclusion may be drawn that both the $\mathrm{Fe}^{2+}$ ions and the $\mathrm{Fe}^{3+}$ ions create complexes with the humic acids (Frimmel 1979; Munter et al. 2005; Albrektiene et al. 2014). There is no unequivocal theory explaining the mechanism of the creation of ion-organic bonds. In the opinion of many authors (Arnold et al. 1998; Hrubec 1995), the iron ions are bound by the humic acids as a result of the electrostatic impact of the metal cation with the negatively charged function groups, and especially the carboxylic groups. According to Gonczarow and Pandey (Gonczarow et al. 2003; Pandey et al. 2000) the formation of chelate complexes with the humic acids in natural waters occurs as a consequence of the reaction of exchanges between the hydrogen ions from the carboxylic and phenolic groups of humic acids, and the ion cations occurring in these conditions, mainly in the form of hydro complexes $[\mathrm{Fe}(\mathrm{OH})]^{2+},\left[\mathrm{Fe}(\mathrm{OH})_{2}\right]^{+}$. Also, it has been concluded that the complex stability constant is increased with an increase in the $\mathrm{pH}$, which is probably caused by the growing dissociation of function groups, i.e. $-\mathrm{COOH}$ and $-\mathrm{OH}$ and smaller competitiveness of $\mathrm{H}^{+}$ions in relation to iron cations, which is present under acid conditions. It is claimed that the strongest water-soluble complexes of iron and humic acid are formed at a $\mathrm{pH}$ of 7 (Rahman et al. 2010; Theis, Singer 1974). In the opinion of many authors (Krupińska et al. 2013; Gonczarow et al. 2003; Calace et al. 2001; Jobin, Ghosh 1972), one of the reasons for iron stabilisation by organic substances in underground waters may also include the formation of "protective colloids" of a hydrophilic nature, which result from the adsorption of organic substances on the surface of the iron (III) hydroxide. The dispersion degree of bonds of iron and organic substances and their stability in water depends on the value of the quotient of organic ligand concentrations in relation to the metal in complex compounds. As the amount of organic substances increases, the stability and degree of the dispersion of iron-organic bonds also increases. Thus, the possibility of their removal within the framework of the conventional process system of underground water treatment is decreased (Krupińska et al. 2013; Gonczarow et al. 2003; Pandey et al. 2000). Knocke et al. (1992) report that, in treated water, if dissolved substances are dominant among the organic substances, iron demonstrates a high degree of complexation, and the forming iron-organic bonds significantly decrease the effectiveness of the oxidisation of $\mathrm{Fe}^{2+}$ to $\mathrm{Fe}^{3+}$ with dissolved oxygen. The application of aeration in such a case is not sufficiently effective, as the sedimenting iron (III) hydroxide agglomerates are not easily precipitated, and only colloidal and water-soluble colourful iron-organic bonds are created (Krupińska et al. 2013; Libecki, Dziejowski 2010). Therefore, various attempts at the intensification of the removal of iron occurring in bonds with organic ligands are made. One of these is the use of chemical oxidising agents instead of aeration (Krupińska et al. 2013; Stępniak et al. 2008). Such technological solutions do not always guarantee the effective removal of iron compounds and organic substances, and in the case of the introduction of chloric oxidising agents into the water, there is a risk of its secondary contamination with side chlorination products (Stępniak et al. 2008; Lytle et al. 2004). The underlying purpose of using ozone or hydrogen dioxide is also arguable, as it may cause the fractionation of large organic particles into smaller particles, and the intermediary organic products from the oxidisation of organic compounds which remain in the water may still stabilise the iron, forming iron-organic bonds, for which the removal via the sedimentation and filtration processes are not sufficient. In an environment that is neutral or close to neutral, and such environments usually occur in natural waters, for the oxidisation of $\mathrm{Fe}(\mathrm{II})$ ions occurring in bonds with organic substances, it is advantageous to use potassium manganate (VII), because $\mathrm{MnO}_{2}$, which improves the sedimentation of iron-organic agglomerates by acting both as the weight and the adsorbent (Krupińska et al. 2013; Ficek, Vella 2000; Knocke et al. 1991; Knocke et al. 1992; Singer et al. 1980), is another product of reaction except $\mathrm{Fe}(\mathrm{OH})_{3}$. The studies conducted by Knocke et al. (1992) proved that the molecular weight of organic ligands determined the effectiveness of the chemical oxidisation of complexed $\mathrm{Fe}(\mathrm{II})$. A significantly greater effectiveness of the oxidisation of $\mathrm{Fe}$ (II) to $\mathrm{Fe}$ (III) and its removal in the sedimentation process was obtained as a result of chemical oxidisation by means of potassium manganate (VII) or chlorine dioxide, when low-molecular and not highmolecular compounds were dominant among the organic ligands as part of the iron-organic complex. One of the ways recommended for intensifying the removal of iron that occurs in a form of stable ferro-organic compounds is application of the coagulation process, preferably with aluminium salt (Krupińska 2012; Albrektiene et al. 2011; Libecki, Dziejowski 2010; Libecki, Dziejowski 2008; Potgieter et al. 2005; O’Melia et al. 1999; Huang, Shiu 1996; Jekel 1986; Dempsey et al. 1984). It has also been found that polymerised polyaluminium chlorides are more effective at removing organic substances and reducing turbidity than aluminium sulphate (VI) (Krupińska 2014; Eikebrokk, Fettig 1990; Dempsey et al. 1985). Better effectiveness of pre-hydrolysed aluminium coagulants is 
caused by the presence of polymeric aluminium complexes with large positive charges, which effectively destabilise and bridge the coloured organic pollution being removed (Edzwald et al. 2000; Edwards, Amirtharajah 1985; Edzwald, Van Benschoten 1990; Tuhkanen et al. 2004; Van Benschoten, Edzwald 1990). The article presents the results of studies concerning the impact of the method of Fe (II) ion oxidisation on the effectiveness of coagulation in the removal of pollutants from underground water with an increased content of organic substances.

\section{Materials and methods}

The subject of the studies was underground water with variable physico-chemical composition (Table 1), characterised by raised colour (up to $38 \mathrm{mgPt} / \mathrm{dm}^{3}$ ), turbidity (38.80 NTU) and a significant content of iron compounds (up to $7.84 \mathrm{mgFe} / \mathrm{dm}^{3}$ ) and manganese (up to $0.42 \mathrm{mgMn}$ / $\mathrm{dm}^{3}$ ). The water contained iron (II) and (III) compounds and dissolved oxygen in the amount of $0.50-1.56 \mathrm{mgO}_{2} /$ $\mathrm{dm}^{3}$, as well as a periodically increased content of organic substances (TOC up to $5.338 \mathrm{mgC} / \mathrm{dm}^{3}$ ). These characteristics of the water were the cause of the unfavourable extent of the removal of iron compounds from it in the conventional system of underground water treatment. The turbidity and intensity of apparent and real colours of water proved the occurrence of iron in the form of colloidal and dissolved bonds with organic compounds, for the removal of which the coagulation process was used. The effectiveness of voluminal coagulation in raw water treatment, after aeration and chemical oxidisation, was determined in the studies. The raw water was aerated with

Table 1. Groundwater quality indicators

\begin{tabular}{lcccc}
\hline \multirow{2}{*}{ Indicator } & \multirow{2}{*}{ Unit } & \multicolumn{3}{c}{ Value } \\
\cline { 3 - 5 } & & Minimum & Average & Maximum \\
\hline Temperature & ${ }^{\circ} \mathrm{C}$ & 6.9 & 11.8 & 17.8 \\
\hline $\mathrm{pH}$ & - & 6.88 & - & 7.25 \\
\hline $\begin{array}{l}\text { Dissolved } \\
\text { Oxygen }\end{array}$ & $\mathrm{mgO}_{2} / \mathrm{dm}^{3}$ & 0.50 & 0.93 & 1.56 \\
\hline Colour & $\mathrm{mgPt} / \mathrm{dm}^{3}$ & 10 & 20 & 38 \\
\hline Turbidity & $\mathrm{NTU}$ & 2.81 & 16.82 & 38.80 \\
\hline Iron total & $\mathrm{mgFe} / \mathrm{dm}^{3}$ & 2.48 & 5.03 & 7.84 \\
\hline Iron $(\mathrm{II})$ & $\mathrm{mgFe} / \mathrm{dm}^{3}$ & 1.20 & 2.80 & 5.84 \\
\hline Iron $(\mathrm{III})$ & $\mathrm{mgFe} / \mathrm{dm}^{3}$ & 0.95 & 2.22 & 4.20 \\
\hline Alkalinity & $\mathrm{mval} / \mathrm{dm}^{3}$ & 3.40 & 3.60 & 3.70 \\
\hline Manganese & $\mathrm{mgMn} / \mathrm{dm}^{3}$ & 0.20 & 0.32 & 0.42 \\
\hline Aluminum & $\mathrm{mgAl} / \mathrm{dm}^{3}$ & 0.09 & 0.13 & 0.17 \\
\hline TOC & $\mathrm{mgC} / \mathrm{dm}^{3}$ & 3.495 & 4.285 & 5.338 \\
\hline $\begin{array}{l}\text { D = [TOC] / } \\
\text { [Iron total] }\end{array}$ & - & 0.640 & 0.860 & 0.943 \\
\hline
\end{tabular}

compressed air for a period of time of $\left(t_{n}\right)$ 15- minutes, obtaining a dissolved oxygen concentration at a level of about $10 \mathrm{mgO}_{2} / \mathrm{dm}^{3}$, that is, about $100 \%$ water saturation with oxygen. Also, chemically pure solutions of $\mathrm{KMnO}_{4}$ or $\mathrm{H}_{2} \mathrm{O}_{2}$ were used to oxidise the $\mathrm{Fe}(\mathrm{II})$ ions; the oxidisation time amounted to $5 \mathrm{~min}$, and the doses of oxidising agents were determined in view of the concentration of $\mathrm{Fe}(\mathrm{II})$ at an amount equal to $100 \%$ of the stoichiometric demand. In certain measurement series after coagulation and 2-hour sedimentation, filtration of samples through a soft filter was additionally added.

The coagulation was performed in water samples with a volume of $1-\mathrm{dm}^{3}$, applying 1-minute of rapid stirring at an intensity of 250-rev./min and 25-minute of flocculation with a stirring intensity of $30-\mathrm{rev} . / \mathrm{min}$. Aluminium sulphate (VI) (SAL), polyaluminium chloride (PAX XL-60) and iron (III) sulphate (VI) - PIX-112, dosed in the form of water solutions were used as coagulants. The doses of coagulants $\left(\mathrm{D}_{\mathrm{c}}\right)$ were expressed in $\mathrm{mgAl} / \mathrm{dm}^{3}$ or $\mathrm{mgFe} / \mathrm{dm}^{3}$ and changed within a range of 1 to $6 \mathrm{mgAl}(\mathrm{Fe}) /$ $\mathrm{dm}^{3}$. The physical-chemical composition of both the raw as well as treated water was determined according to the International Standard methods. The temperature and $\mathrm{pH}$ of the raw water and the purified water was determined with an WTW Multi Line P4 with an combination pH electrode with temperature corrections. The instrument was standardized daily using a two point calibration with pH 4 and 7 standard solutions. The dissolved oxygen of the raw water and the purified water was determined with an WTW Multi 3410 SET 4 with an optical oxygen sensor $\mathrm{FDO}^{\mathrm{R}} 925$ (Germany). The turbidity was determined by means of 2100P HACH turbidimeter. The colour (according to $\mathrm{Pt}$ scale), total iron, iron (II) concentrations were determined with the Dr 3900 (HACH Lange) spectrophotometer. For determination of water colour, water samples were filtrated through $0.45 \mu \mathrm{m}$ membrane filters. Water colour was measured in $5 \mathrm{~cm}$ cell with $390 \mathrm{~nm}$ wavelength Dr 3900 (HACH Lange) Spectrophotometer. Iron (II) was measured using the 1,10 phenanthroline method. Total iron was measured using the same method except that a reducing reagent was also included in a reagent powder pillow to convert $\mathrm{Fe}$ (III) to $\mathrm{Fe}(\mathrm{II})$. Iron (III) was determined from the difference in the content of iron total and iron (II). Aluminum and manganese concentrations were determined with the plasma emission method (ICP-OES, 5300DV, Perkin Elmer Company, US). The alkalinity was determined with a titrimetric method against methyl orange. The organic carbon content was measured with a Shimadzu TOC apparatus. Prior to TOC measurement, the samples were acidified and bubbled with air, which did not contain any $\mathrm{CO}_{2}$, in order to remove the inorganic carbon. Raw and treated water samples were analyzed in the laboratory of University of Zielona Góra, Institute of Environmental Engineering (Poland).The coefficient of 
the co-occurrence of organic substances and total iron $\mathrm{D}$, calculated as $\mathrm{D}=[\mathrm{TOC}] /\left[\mathrm{Fe}_{\text {tot }}\right](\mathrm{mgC} / \mathrm{mgFe})$ was used in the interpretation of the results of the studies, for the assessment of the level of organic pollution of the water samples and its impact on the course and effectiveness of the coagulation process, whereby in order to simplify the formula, the unit of the coefficient $\mathrm{D}$ was not given in the article. A decrease in the values of the studied water quality indicators in relation to the values permissible in the water for human consumption was assumed as the required effectiveness of water treatment.

\section{Results and discussion}

During the studies, the course and effectiveness of coagulation in raw water treatment and after Fe (II) oxidisation was determined. The effects of water treatment in technological systems were assessed:

- coagulation, 2-hour sedimentation;

- Fe (II) oxidisation, coagulation, 2-hour sedimentation (additional filtration through soft filter paper).

\subsection{The impact of water aeration on the effectiveness of its treatment}

Comparison of the effects of raw and aerated water showed unambiguously that in view of the necessity of increasing the degree of the removal of iron compounds and reducing the intensity of the colour and turbidity of water, its aeration was required before the coagulation process (Figs $1 \mathrm{a}, \mathrm{b}$ and $2 \mathrm{~b}$ ).

The water aeration was, on the other hand, disadvantageous in terms of the removal of organic substances (Fig. 2a). This relationship was confirmed by the contents of organic substances (which increased together with the dose of the coagulant) in post-coagulation sludge separated from non-aerated water and after aeration (Table 2).

Table 2. Content of organic substances in the dry mass of postcoagulation sludge $\left(D_{c}=1-6 \mathrm{mgAl} / \mathrm{Fe} / \mathrm{dm}^{3}\right)$ separated from raw water and aerated water

\begin{tabular}{lccc}
\hline \multirow{2}{*}{$\begin{array}{l}\text { Kind of water } \\
\text { being purified }\end{array}$} & \multicolumn{3}{c}{$\begin{array}{c}\text { Organic substances \% in the dry mass } \\
\text { of post-coagulation }\end{array}$} \\
\cline { 2 - 4 } & SAL & PAX XL-60 & PIX-112 \\
\hline Non-aerated & $14.3-31.4$ & $16.3-33.8$ & $11.0-25.0$ \\
\hline Aerated & $8.1-19.0$ & $14.9-21.1$ & $7.0-16.0$ \\
\hline
\end{tabular}

An increase in the $\mathrm{pH}$ of the water (by about 1 unit) as a result of aeration probably caused a simultaneous decrease in the amount of products of the hydrolysis of coagulants with positive charges (e.g. $\mathrm{AlOH}^{2+}, \mathrm{Al}(\mathrm{OH})_{2}^{+}$, $\mathrm{FeOH}^{2+}, \mathrm{Fe}(\mathrm{OH})_{2}^{+}$) and an increase in the degree of the dissociation of organic compounds, which decreased the effectiveness of the removal of organic pollutants
(Krupińska 2012; Libecki, Dzejowski 2008). Comparison of the effectiveness of the studied coagulants showed the greatest effectiveness using the prehydrolyzed coagulant (PAX XL-60), especially in terms of small doses. The advantages of polyaluminium chloride also included the decreased acidification of water and a smaller consumption of total alkalinity, which is significant in the aspect of the removal of iron and manganese compounds and the chemical stability of water. Within the range of doses used, an average unit consumption of total alkalinity was: $0.10 \mathrm{mval} / \mathrm{mgAl}$ (SAL), $0.07 \mathrm{mval} / \mathrm{mgAl}$ (PAX XL-60) and $0.09 \mathrm{mval} / \mathrm{mgFe}$ (PIX-112). The studies conducted by Edzwald et al. (2000) proved that the pre-hydrolyzed coagulants cause smaller consumption of the natural water alkalinity and lower its $\mathrm{pH}$ reaction to a smaller extent than coagulants that are not pre-hydrolyzed.

The effectiveness of iron (III) sulphate (VI), irrespective of the type of polluted water (raw or aerated water),

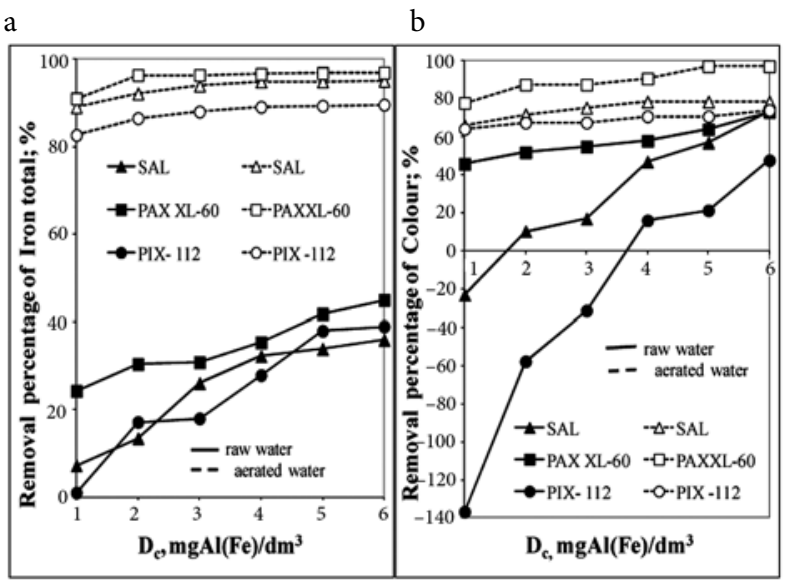

Fig. 1. Comparison of effectiveness of coagulation and 2-hour sedimentation in the reduction of: (a) the concentration of total iron and (b) colour in raw water or after aeration

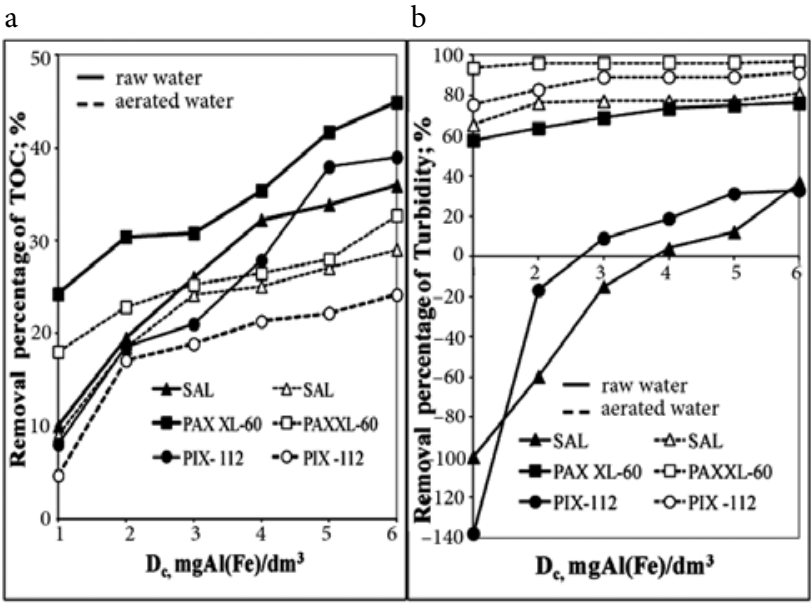

Fig. 2. Comparison of the effectiveness of coagulation and 2-hour sedimentation in the reduction of (a) TOC and (b) turbidity in raw water or after aeration 
Table 3. The impact of the value of coefficient $\mathrm{D}\left(\mathrm{TOC} / \mathrm{Fe}_{\mathrm{og}}\right)$ and the type of coagulant $\left(\mathrm{D}_{\mathrm{k}}=3 \mathrm{mgAl}(\mathrm{Fe}) / \mathrm{dm}^{3}\right)$ on the effectiveness of the removal of pollutants $(\eta)$ from raw water and from water after aeration

\begin{tabular}{|c|c|c|c|c|c|c|c|}
\hline $\begin{array}{l}\text { Type of } \\
\text { coagulant }\end{array}$ & $\begin{array}{l}\text { Type of } \\
\text { oxidant }\end{array}$ & $\mathrm{D}$ & $\eta_{\text {Feog }}$ & $\eta_{\mathrm{B}}$ & $\eta_{\mathrm{M}}$ & $\mathrm{h}_{\text {тос }}$ & $\eta_{\mathrm{Mn}}$ \\
\hline \multirow{4}{*}{ SAL } & \multirow{2}{*}{ - } & 0.640 & 56 & 65 & 80 & 31 & 5 \\
\hline & & 0.846 & 27 & 17 & 15 & 26 & 5 \\
\hline & \multirow{2}{*}{$\mathrm{O}_{2}$} & 0.780 & 95 & 77 & 85 & 24 & 15 \\
\hline & & 0.823 & 90 & 73 & 77 & 21 & 15 \\
\hline \multirow{4}{*}{ PIX-112 } & \multirow{2}{*}{-} & 0.810 & 50 & 33 & 84 & 22 & 13 \\
\hline & & 0.838 & 25 & 31 & 80 & 20 & 13 \\
\hline & \multirow{2}{*}{$\mathrm{O}_{2}$} & 0.601 & 89 & 70 & 90 & 20 & 20 \\
\hline & & 0.722 & 85 & 67 & 87 & 17 & 20 \\
\hline \multirow{4}{*}{$\begin{array}{l}\text { PAX } \\
\text { XL-60 }\end{array}$} & \multirow{2}{*}{ - } & 0.654 & 60 & 80 & 91 & 39 & 7 \\
\hline & & 0.832 & 51 & 54 & 69 & 31 & 7 \\
\hline & \multirow{2}{*}{$\mathrm{O}_{2}$} & 0.763 & 96 & 87 & 97 & 28 & 17 \\
\hline & & 0.943 & 94 & 81 & 94 & 25 & 17 \\
\hline
\end{tabular}

a

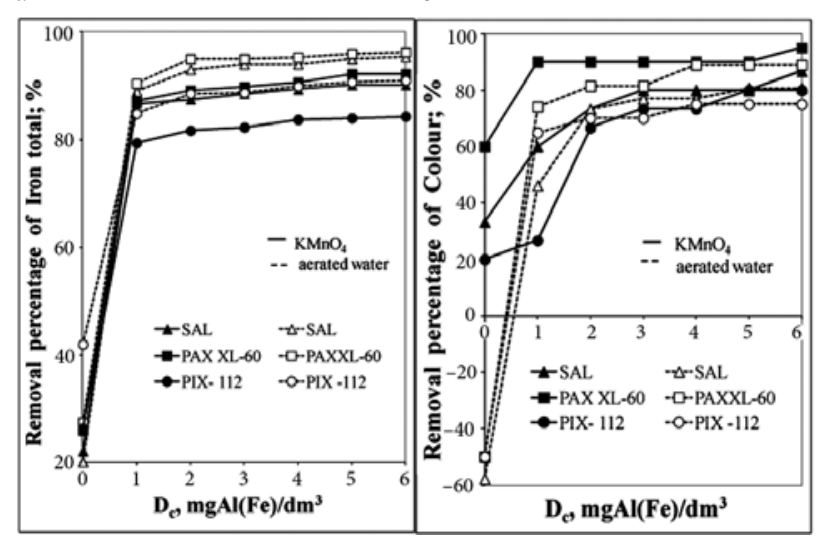

Fig. 3. Comparison of the effectiveness of coagulation and 2-hour sedimentation in the reduction of the total iron concentration (a) and colour (b) in water after oxidisation with $\mathrm{KMnO}_{4}$ or after aeration

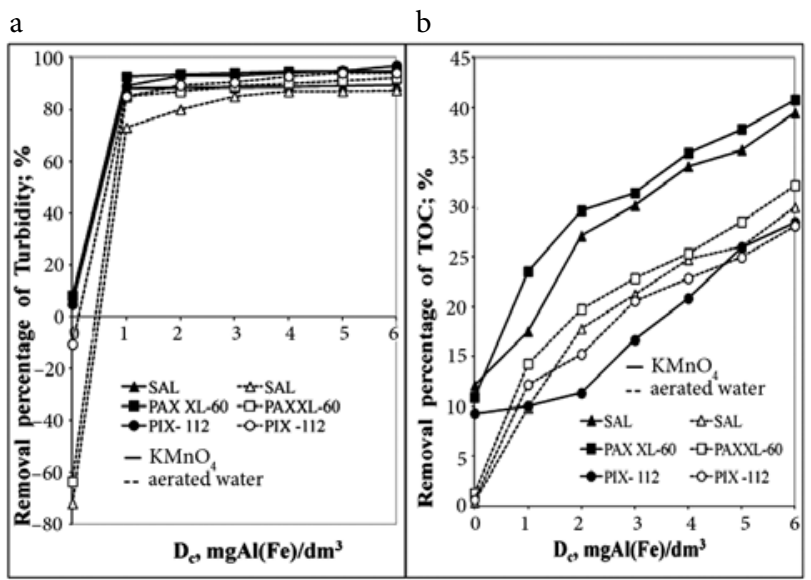

Fig. 4. Comparison of the effectiveness of coagulation and 2-hour sedimentation in reducing the turbidity (a) and concentration of total organic carbon (b) in water after oxidisation with $\mathrm{KMnO}_{4}$ or after aeration was only greater than that of the aluminium coagulant of aluminium sulphate (VI) (SAL) in reducing the turbidity and removing the manganese compounds, and even greater than PAX XL-60 coagulant. The greater effectiveness of iron (III) sulphate (VI) than aluminium sulphate (VI) in reducing the turbidity was probably caused by the greater density of $\mathrm{Fe}(\mathrm{OH})_{3}$ than $\mathrm{Al}(\mathrm{OH})_{3}$, and thus meaning better sedimentation properties of post-coagulation suspensions. The results of the studies have shown that coagulation with the studied coagulants was completely ineffective in removing manganese compounds from both non-aerated water and aerated water. This was caused by the low $\mathrm{pH}$ content, which was confirmed by an increase in the concentration of manganese in the treated water as the dose of coagulants and concentration of $\mathrm{H}^{+}$ ions increased. The greatest but insufficient effectiveness of coagulant PIX-112 in removing the manganese compounds (Table 3) was probably the effect of the adsorption of manganese on iron (III) hydroxide, whose additional amounts were produced in samples of water treated with iron (III) sulphate (VI). Comparison of the effectiveness of the removal of pollutants from underground raw or aerated water (Table 3), differing in terms of the values of the coefficients of the co-occurrence of organic pollutants and total iron $\left(\mathrm{D}=\mathrm{TOC} / \mathrm{Fe}_{\text {tot }}\right)$ proved that, irrespective of the type of the coagulant, the effectiveness of decreasing the concentration of total iron, reducing the colour and the turbidity and removing the organic substances was lower for the greater values of coefficient $\mathrm{D}$.

The relationships found prove the stabilisation of iron compounds by organic substances. The regularity found proves book references (Eikebrokk, Fettig 1990; Dempsey et al. 1985; Edzwald et al. 2000; Krupińska 2014) stating that an increase of the amount of organic ligands in raw water strengthens durability / life of organoferric combinations as well as the contribution of dissolved coloured, organoferric complexes, difficult to remove in the coagulation process.

\subsection{The effects of the removal of pollutants from water after oxidisation using potassium manganate (VII)}

The effects of the removal of pollutants from the water after oxidisation with potassium manganate (VII) showed that the precipitating manganese (IV) oxide increased the effectiveness of the removal of pollutants from the water. Comparison of the effects of coagulation and sedimentation in the treatment of aerated water and water after oxidisation with potassium manganate (VII) showed that the application of $\mathrm{KMnO}_{4}$ as an oxidising agent was much better than oxidisation with regards to the degree of the reduction in colour, turbidity and concentration of manganese and organic substances (except coagulant PIX-112), but unfortunately worse with respect to iron removal (Figs 3 and 4). 


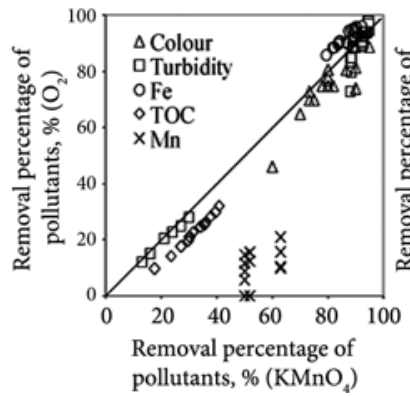

$\mathrm{b}$

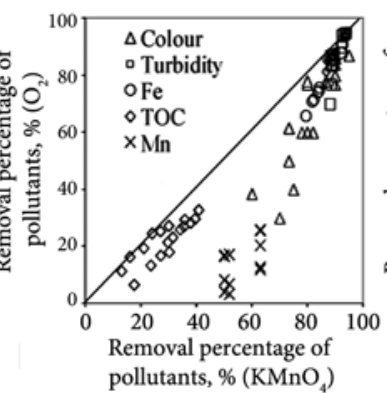

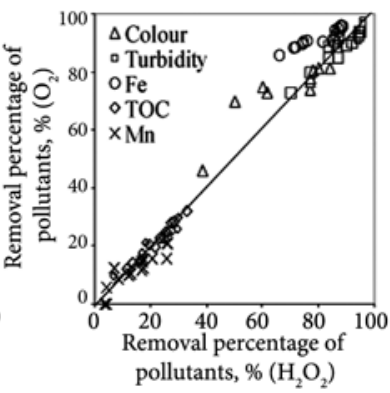

Fig. 5. The impact of the type of oxidising agent: a) dissolved oxygen and $\left.\mathrm{KMnO}_{4}, \mathrm{~b}\right) \mathrm{H}_{2} \mathrm{O}_{2}$ and $\mathrm{KMnO}_{4}, \mathrm{c}$ ) dissolved oxygen and $\mathrm{H}_{2} \mathrm{O}_{2}$ on the effects of the removal of pollutants in the coagulation process (SAL, PAX XL-60, PIX-112) and 2-hour sedimentation

The probable reason for the worse effects of the removal of iron from water after oxidisation with $\mathrm{KMnO}_{4}$ was the decrease in the efficiency of oxidisation of the $\mathrm{Fe}(\mathrm{II})$ to $\mathrm{Fe}(\mathrm{III}),\left(\left(\eta_{\mathrm{Fe}(\mathrm{II})-\mathrm{Fe}(\mathrm{III})}=92 \%\left(\mathrm{O}_{2}\right) ; \eta_{\mathrm{Fe}(\mathrm{II})-\mathrm{Fe}(\mathrm{III})}=\right.\right.$ $\left.86 \%\left(\mathrm{KMnO}_{4}\right)\right)$; caused by the lower $\mathrm{pH}$ value than in the water samples after aeration $\left(\left(\mathrm{pH}=8\left(\mathrm{O}_{2}\right) ; \mathrm{pH}=7\right.\right.$ $\left.\left(\mathrm{KMnO}_{4}\right)\right)$.

The lack of any increase in the $\mathrm{pH}$ in water after oxidisation with potassium manganate (VII) additionally precipitated manganese (IV) oxide was, on the other hand, favourable in terms of the removal of the organic substances. According to Ficek and Vella (2000) application of potassium manganate (VII) to drinking water treatment systems can help solve a number of problems. It is a versatile oxidant that will react with organic compounds easily breaking carbon-carbon double bonds and oxidizing functional groups. The comparison of the usefulness of the studied coagulants in the removal of pollutants from water after oxidisation of $\mathrm{Fe}$ (II) with potassium (VII) manganate, just as in the case of the treatment of raw and aerated waters, confirmed the greatest effectiveness of coagulant which was prehydrolyzed with PAX XL60 . Also, the concentration of the residual aluminium was determined in the studies. It was ascertained that also in this aspect, polyaluminium chloride was more useful than aluminium sulphate (VI). The lowest aluminium concentrations $\left(0.28-0.22 \mathrm{mgAl} / \mathrm{dm}^{3}\right)$ were found in water after oxidisation with potassium (VII) manganate and coagulation with coagulant PAX XL-60 $\left(\mathrm{D}_{\mathrm{c}}=1-6 \mathrm{mgAl} / \mathrm{dm}^{3}\right)$ (see Fig. 7). Also according to Van Benschoten, Edzwald (1990), substitution of aluminium sulphate(VI) by polyaluminium chlorides reduced the concentration of aluminium residual in water after coagulation. The conducted studies also showed that if $\mathrm{KMnO}_{4}$ was used for the oxidisation of the $\mathrm{Fe}(\mathrm{II})$ before the process of coagulation with aluminium sulphate (VI), polyaluminium chloride and iron (III) sulphate (VI), the impact of the coefficient $\mathrm{D}$ on the effectiveness of the removal of pollutants was not unambiguous.

\subsection{The impact of oxidisation with hydrogen peroxide on the degree of removal of pollutants}

Analysis of the relationships presented in Figure 5 proved that the worst effects regarding the removal of pollutants from water were obtained as a result of the application of $\mathrm{H}_{2} \mathrm{O}_{2}$ for the oxidisation of $\mathrm{Fe}(\mathrm{II})$. The application of aeration before the coagulation process was the most effective in view of the removal of iron compounds, and potassium manganate (VII) - with regards to reducing the colour, turbidity and concentrations of the total organic carbon and manganese.

The degree of the removal of manganese from water samples in which $\mathrm{KMnO}_{4}$ was applied as the oxidising agent was constant and did not depend on the dose of the coagulant. On the other hand, in the case of preceding the coagulation with aeration or oxidisation with hydrogen peroxide, the effectiveness of the removal of manganese was reduced together with an increase in the dose of the studied coagulants (Fig. 6).

Irrespective of the type of the oxidising agent $\left(\mathrm{O}_{2}\right.$, $\mathrm{KMnO}_{4}, \mathrm{H}_{2} \mathrm{O}_{2}$ ) used, with regards to the concentration of

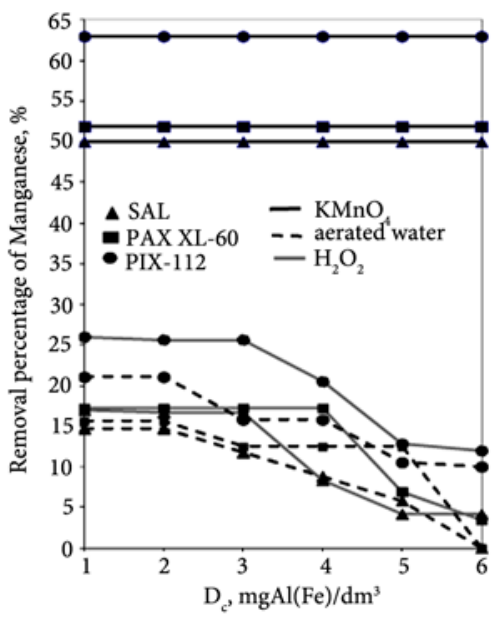

Fig. 6. The impact of the type and dose of coagulant and the oxidising agent used on the effectiveness of the removal of manganese from water (2-hour sedimentation) 
aluminium left in the water treated with aluminium coagulants, coagulant PAX XL-60 was more effective than aluminium sulphate (VI). Eikebrokk and Fettig (1990) and Edzwald et al. (2000) believe that polyaluminium

a
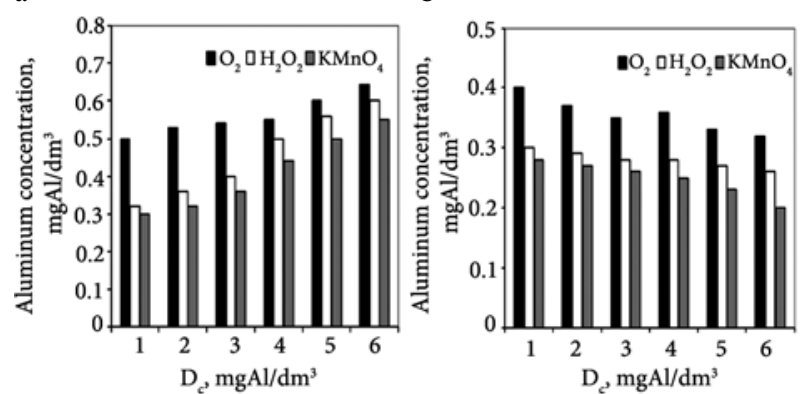

Fig. 7. The impact of the type and dose of coagulant and the oxidising agent on the change of aluminium concentration: a) SAL; b) PAX XL-60

Table 4. Required doses of coagulants $\left(\mathrm{D}_{\mathrm{re}}\right)$ ensuring a comparable degree of reduction in the concentration of total iron and organic pollutants, and causing colour and water turbidity in coagaulation and sedimentation

\begin{tabular}{lcccc}
\hline $\begin{array}{c}\text { Type of } \\
\text { coagu- } \\
\text { lant }\end{array}$ & \multicolumn{4}{c}{$\mathrm{D}_{\mathrm{re}} \mathrm{mgAl}(\mathrm{Fe}) / \mathrm{dm}^{3}$} \\
\cline { 2 - 5 } & Iron total & Colour & Turbidity & TOC \\
\hline SAL & $\mathrm{D}_{\mathrm{c}}<1$ & $1<\mathrm{D}_{\mathrm{c}}<2$ & $\mathrm{D}_{\mathrm{c}}>6$ & $4<\mathrm{D}_{\mathrm{c}}<5$ \\
\hline PIX-112 & $\mathrm{D}_{\mathrm{c}}=6$ & $\mathrm{D}_{\mathrm{c}}=6$ & $\mathrm{D}_{\mathrm{c}}=6$ & $\mathrm{D}_{\mathrm{c}}=6$ \\
\hline PAX & $\mathrm{D}_{\mathrm{c}}<1$ & $\mathrm{D}_{\mathrm{c}}<1$ & $3<\mathrm{D}_{\mathrm{c}}<4$ & $4<\mathrm{D}_{\mathrm{c}}<5$ \\
\hline XL-60 & & & & \\
\hline
\end{tabular}

Table 5. Parameters of lineral regression between the amount of TOC removed and the amount of Fe(III) removed in the coagulation proces

\begin{tabular}{|c|c|c|c|}
\hline $\begin{array}{l}\text { Type of } \\
\text { oxidant }\end{array}$ & $\begin{array}{l}\text { Type of } \\
\text { coagulant }\end{array}$ & $\begin{array}{c}\text { Linear regression } \\
\text { equation }\end{array}$ & $\begin{array}{l}\text { Coefficient of } \\
\text { determination } \\
\left(\mathrm{R}^{2}\right)\end{array}$ \\
\hline \multirow{3}{*}{$\mathrm{O}_{2}$} & SAL & $\begin{array}{l}\text { hTOC }=1.8127 \eta \mathrm{Fe}(\mathrm{III}) \\
-147.12\end{array}$ & 0.9465 \\
\hline & $\begin{array}{l}\text { PAX XL- } \\
60\end{array}$ & $\begin{array}{l}\text { hTOC }=1.3197 \eta \mathrm{Fe}(\mathrm{III}) \\
-97.101\end{array}$ & 0.9401 \\
\hline & PIX-112 & $\begin{array}{l}\text { hTOC }=1.9361 \eta \mathrm{Fe}(\mathrm{III}) \\
-143.74\end{array}$ & 0.9631 \\
\hline \multirow{3}{*}{$\mathrm{KMnO}_{4}$} & SAL & $\begin{array}{l}\text { hTOC }=1.505 \eta \mathrm{Fe}(\mathrm{III}) \\
-88.805\end{array}$ & 0.9457 \\
\hline & $\begin{array}{l}\text { PAX XL- } \\
60 \\
\end{array}$ & $\begin{array}{l}\text { hTOC }=1.826 \eta \mathrm{Fe}(\mathrm{III}) \\
-121.40\end{array}$ & 0.9588 \\
\hline & PIX-112 & $\begin{array}{l}\text { hTOC }=2.2558 \eta \mathrm{Fe}(\mathrm{III}) \\
-133.13\end{array}$ & 0.9483 \\
\hline \multirow{3}{*}{$\mathrm{H}_{2} \mathrm{O}_{2}$} & SAL & $\begin{array}{l}\text { hTOC }=1.7238 \eta \mathrm{Fe}(\mathrm{III}) \\
-110.34\end{array}$ & 0.9493 \\
\hline & $\begin{array}{l}\text { PAX XL- } \\
60\end{array}$ & $\begin{array}{l}\text { hTOC }=2.0134 \eta \mathrm{Fe}(\mathrm{III}) \\
-161.71\end{array}$ & 0.9843 \\
\hline & PIX-112 & $\begin{array}{l}\text { hTOC }=1.0709 \eta \mathrm{Fe}(\mathrm{III}) \\
-39.416\end{array}$ & 0.9793 \\
\hline
\end{tabular}

chlorides are more effective than aluminium sulphate (VI). The higher efficiency of polyaluminium chloride than aluminium sulphate (VI) is attributable to the fact that the solutions of polyaluminium chloride contain (in addition to aluminium monomers) large quantities of polycationic products generated during prehydrolysis of aluminium, which effectively neutralize the negative charges of the colloids (Krupińska 2014; Eikebrokk, Fettig 1990; Dempsey et al. 1985). On top of this, irrespective of the type of oxidising agent $\left(\mathrm{O}_{2}, \mathrm{KMnO}_{4}, \mathrm{H}_{2} \mathrm{O}_{2}\right)$ used, the concentration of residual aluminium after coagulation with polyaluminium chloride was reduced together with an increase in the dose of the coagulant, and after the coagulation with aluminium sulphate (VI), the reverse relationship was found (Fig. 7).

Comparison of the doses of coagulants ensuring a similar degree of reduction in the concentration of total iron (76\%), colour (60\%), turbidity (95\%) and TOC (27\%) in water samples in which hydrogen peroxide was used as the oxidising agent, confirmed unambiguously the greatest effectiveness of coagulant PAX XL-60, and among the non-hydrolyzed coagulants, a preliminarily greater effectiveness of aluminium sulphate (VI) than iron (III) sulphate (VI) (except for reduction in turbidity) (Table 4).

Analysis of the results of the studies presented in Table 5 showed that irrespective of the oxidising agent used, an increase in the effectiveness of coagulation and sedimentation in the removal of $\mathrm{Fe}$ (III) resulted in an increase in the degree of the removal of TOC, which proves the removal of $\mathrm{Fe}$ (III) together with the organic substances, and thus, the occurrence of iron in iron-organic bonds in water. In the water samples in which $\mathrm{H}_{2} \mathrm{O}_{2}$ or $\mathrm{KMnO}_{4}$ were used for oxidisation of $\mathrm{Fe}$ (II), no relationship between the effectiveness of the removal of pollutants and the value of the quotient of the TOC concentrations to total iron (D) were found. The required values of colour $(15 \mathrm{mg} \mathrm{Pt} /$ $\left.\mathrm{dm}^{3}\right)$, turbidity (1NTU) and concentrations of total iron $\left(0.2 \mathrm{mg} \mathrm{Fe} / \mathrm{dm}^{3}\right)$ and residual aluminium $\left(0.2 \mathrm{mg} \mathrm{Al} / \mathrm{dm}^{3}\right)$ were obtained only after additional filtration through a soft filter. To obtain the required degree of water treatment, the filtration of water samples after sedimentation of post-coagulation suspensions was redundant only after using $\mathrm{KMnO}_{4}$ and the most effective coagulant (PAX XL$\left.60\left(\mathrm{D}_{\mathrm{c}}=5 \mathrm{mgAl} / \mathrm{dm}^{3}\right)\right)$.

\section{Conclusions}

The test results analysis leads to the following conclusions:

1. In the case of treatment of groundwater with an increased content of organic substances and iron, it was necessary to oxidise Fe (II) ions prior to the coagulation process.

2. The application of potassium manganate (VII) for oxidation of $\mathrm{Fe}$ (II) ions produced the best results 
in terms of reduction in colour, turbidity and concentration of manganese and organic substances. Hydrogen peroxide was the least useful oxidising agent.

3 . In the case of the treatment of raw water or aerated water, the effectiveness of the coagulation process was determined by the value of the coefficient of the co-occurrence of organic substances and total iron. As its value in the treated water increased, the effectiveness of coagulation and sedimentation in the removal of pollutants (except manganese compounds) decreased. This regularity was not observed when hydrogen peroxide and potassium manganate (VII) was used to oxidise Fe (II).

4. Regardless of the oxidising agent the best results in the removal of pollutants in the coagulation process were produced by the coagulant: pre-hydrolysed polyaluminium chloride PAX XL-60, and the worst by the iron coagulant: iron (III) sulphate (VI). The lowest usefulness of the iron coagulant for removing iron and organic compounds, and for decreasing the colour intensity in water was probably caused by the interaction of organic ligands and $\mathrm{Fe}(\mathrm{III})$ ions introduced into the water with the coagulant.

5. In the coagulation process Fe (III) compounds were removed together with organic substances, which means that they occurred in the water undergoing treatment in the form of colloidal ferrous-organic compounds which could only be removed in the coagulation process.

6. An analysis of the research results also shows that when groundwater with an increased content of organic substances is treated, the coagulation process for polyaluminium chloride should be aided with a chemical oxidising agent, preferably with a potassium manganate (VII) because apart from iron(III) hydroxide, manganese (IV) oxide is also produced in the process of oxidation. It acts as an extender and adsorbent improving the sedimentation characteristics of ferrous-organic agglomerates, which are difficult to remove in a conventional technological system for groundwater treatment.

\section{References}

Albrektiene, R.; Rimeika, M.; Lubyte, E. 2011. The removal of ironorganic complexes from drinking water using coagulation process, in The 8th International Conference "Environmental Engineering", 19-20 May 2011, Vilnius, Lithuania, 509-512.

Albrektiene, R.; Rimeika, M.; Grazeniene, R. 2014. Organic fractions and metal-organic complexes in the groundwater, in The 9th International Conference "Environmental Engineering”, 22-23 May 2014, Vilnius, Lithuania Selected Papers. Article number: enviro.2014.070.
Arnold, C. G.; Ciani, A.; Müller, S. R.; Amirbahman, A.; Schwarzenbach, R. P. 1998. Association of triorganotin compounds with dissolved humic acids, Environmental Science Technologii 32(19): 2976-2983. http://dx.doi.org/10.1021/es980114z

Calace, N.; Liberatori, A.; Petronio, B. M.; Pietroletti, M. 2001. Characteristic of different molecular weight fractions of organic matter in landfill leachate and their role in soil sorption of heavy metals, Environmental Pollution 113(3): 331-339. http://dx.doi.org/10.1016/S0269-7491(00)00186-X

Dempsey, B. A.; Ganho, R. M.; O Melia, C. R. 1984. The coagulation of humic substances by means of aluminum salts, Journal American Water Works Association 76(4): 141-150.

Dempsey, B. A.; Sheu, H.; Tanzeer Ahmed, T. M.; Mentink, J. 1985. Polyaluminum chloride and alum coagulation of clay fulvic acid suspensions, Journal American Water Works Association $77(3)$ : 74-80.

Edwards, A.; Amirtharajah, A. 1985. Removing color caused by humic acids, Journal American Water Works Association 77 (3): 50-57.

Edzwald, J.; Pernitsky, D.; Paramenter, W. 2000. Polyaluminum coagulants for drinking water treatment, chemistry and selection, in H. Hahn, E. Hoffmann, H. Ødegaard (Eds.). Chemical Water and Wastewater Treatment VI. Berlin: Springer-Verlag, 341-359.

http://dx.doi.org/10.1007/978-3-642-76093-8_22

Edzwald, J.; Perntsky, D.; Paramenter, W. 2000. Polyaluminum coagulants for drinking water treatment, chemistry and selection, Chemical Water and Wastewater Treatment VI Berlin: Springer-Verlag, 3-14.

Eikebrokk, B.; Fettig, J. 1990. Treatment of coloured surface water by coagulation. Direct filtration: effect of water quality, type of coagulant and filter aids, in R. Klute, H. Hahn (Eds.). Chemical Water and Wastewater Treatment. Berlin: SpringerVerlag, 361-376.

Ficek, K.; Vella, P. 2000. Potassium permanganate the oxidation solution to many water treatment problems, in IV International Conference "Water Supply and Water Quality", 11-13 September 2000, Kraków, Poland, 673-684.

Frimmel, F. H. 1979. Untersuchungen zur Komplexbildung des Eisens mit Huminstoffen eines Gewässers, Vom Wasser 53: 243-247.

Gimbel, R.; Jekel, M.; Ließfeld, R. 2008. Podstawy i technologie uzdatniania wody. Bydgoszcz: Projprzem-EKO.

Gonczarow, T. O.; Kołosow, I. W.; Kapli, W. 2003. O formach nachorzdjenija metallow w poijerchnowstnych wodach, Gidrometeoizdat 77: 73-89.

Hrubec, J. 1995. The handbook of environmental chemistry 5.B. Quality and treatment of drinking water. Berlin, Heidelberg: Springer-Verlag.

Huang, C.; Shiu, H. 1996. Interactions between alum and organics in coagulation, Colloids and Surface 113: 155-163. http://dx.doi.org/10.1016/0927-7757(96)03543-1

Jekel, M. R. 1986. Interactions of humic acids and aluminum salts in the flocculation process, Water Research 29(12): 1535-1542. http://dx.doi.org/10.1016/0043-1354(86)90118-1

Jobin, R.; Ghosh, M. M. 1972. Effect of buffer intensity and organic matter on the oxygenation of ferrous iron, Journal American Water Works Association 64(9): 590-595.

Knocke, R. W.; VanBenschoten, J. E.; Kearney, M. J.; Soborski, A. W.; Reckhow, A. 1991. Kinetics of manganese and iron 
oxidation by potassium permanganate and chlorine dioxide, Journal American Water Works Association 83(6): 80-87. http://dx.doi.org/10.1016/0043-1354(92)90072-C

Knocke, R. W.; Conley, L.; Van Benschoten, J. E. 1992. Impact of dissolved organic carbon on the removal of iron during water treatment, Water Research 26(11): 1515-1522.

Krupińska, I. 2012. Przydatność koagulacji w oczyszczaniu wody podziemnej, Annual Set the Environmental Protection 14: 491-501.

Krupińska, I.; Kowalczyk, W.; Szczepaniak, G. 2013. Wpływ wartości współczynnika współwystępowania substancji organicznych i żelaza ogólnego w wodzie podziemnej na skuteczność jej oczyszczania, Ochrona Środowiska 35(3): 27-34.

Krupińska, I. 2014. Effect of the type of aluminium coagulant on effectiveness at removing pollutants from groundwater in the process of coagulation, in The 9th International Conference "Environmental Engineering", 22-23 May 2014, Vilnius, Lithuania: Selected Papers.

http://dx.doi.org/10.3846/enviro.2014.082

Libecki, B.; Dziejowski, J. 2008. Optimization of humic acids coagulation with aluminum and iron(III) salts, Polish Journal of Environmental Study 17(3): 397-403.

Libecki, B.; Dziejowski, J. 2010. Changes in iron(II) and iron(III) content in solution of humic acids during coagulation by means of monomeric iron(III) salts, Polish Journal of Environmental Study 19(5): 1089-1093.

Lytle, D. A.; Magnuson, M.; Snoeyink, V. L. 2004. Effect of oxidants on the properties of $\mathrm{Fe}(\mathrm{III})$ particles and suspensions formed from the oxidation of Fe(II), Journal American Water Works Association 96(8): 112-124.

Munter, R.; Ojeaste, H.; Sutt, J. 2005. Complexed iron removal from groundwater, Journal of Environmental Engineering 7(1): 1014-1020. http://dx.doi.org/10.1061/(ASCE)07339372(2005)131:7(1014)

O’Melia, C. R.; Becker, W. C.; Au, K. K. 1999. Removal of humic acid substances by coagulation, Water Science and Technology 40(9): 47-55. http://dx.doi.org/10.1016/S0273-1223(99)00639-3
Pandey, A. K.; Pandey, S. D.; Mistra, V. 2000. Stability constants of metal-humic acid complexes and its role in environmental detoxification, Ecotoxicology and Environmental Safety 47(2): 195-200.

http://dx.doi.org/10.1006/eesa.2000.1947

Potgieter, J. H.; Mccrindle, R. I.; Sihlali, Z.; Schwarzer, R.; Basson, N. 2005. Removal of iron and manganese from water with a high organic carbon loading. Part 1: The effect of various coagulants, Water, Air and Soil Pollution 162(4): 49-59. http://dx.doi.org/10.1007/s11270-005-5992-x

Rahman, M. A.; Hasan, M. A.; Rahim, A.; Shafigul Alam, A. M. 2010. Characterization of humic acid from the river bottom sediments of Burigonga: Complexation studies of metals with humic acid, Pakistan Journal of Analytical and Environmental Chemistry 11(1): 42-52.

Singer, P. C.; Borchardt, J. M.; Colthurst, J. M. 1980. The effects of permanganate pretreatment on trihalomethane formation in drinking water, Journal American Water Works Association 72(10): 573-578.

Stępniak, L.; Kępa, U.; Stańczyk-Mazanek, E. 2008. The research on the possibility of ultrasound field application in iron removal of water, Desalination 223: 180-186. http://dx.doi.org/10.1016/j.desal.2007.01.212

Theis, T. L.; Singer, P. C. 1974. Complexation of iron(III) by organic matter and its effect on iron(III) oxygenation, Environmental Science and Technology 8(6): 569-573. http://dx.doi.org/10.1021/es60091a008

Tuhkanen, T.; Ketonen, A.; Gilberg, L.; Jahela, J. 2004. Removal of different size fractions of natural organic matter in drinking water by optimised coagulation, Chemical Water and Wastewater Treatment. Berlin. Springer-Verlag: 201-207.

Van Benschoten, J. E.; Edzwald, J. K. 1990. Chemical aspects of coagulation using aluminum salts-II. Coagulation of fulvic acid using alum and polyaluminum chloride, Water Research 24(12): 1527-1535. http://dx.doi.org/10.1016/0043-1354(90)90087-M

Izabela KRUPIŃSKA. Doctor of Technological Sciences (Environmental Engineering since 2006). Associate Professor at the University of Zielona Góra Institute of Environmental Engineering, Poland. Author of 31 scientific publications. Research interests: environmental chemistry, treatment of water, treatment of groundwater with a high amount of organic substances. 